DOI 10.37882/2500-3682.2021.04.13

\title{
ПЕРСОНАЛИСТИЧЕСКОЕ БОГОСЛОВИЕ АРХИМАДРИТА СОФРОНИЯ (САХАРОВА) И ТРИАДОЛОГИЧЕСКОЕ УЧЕНИЕ ПРАВОСЛАВНОЙ ЦЕРКВИ
}

\section{THE PERSONALISTIC THEOLOGICAL STUDIES OF ARCHIMADRITE SOPHRONY (SAKHAROV) AND THE TRIADOLOGICAL TEACHING OF THE ORTHODOX CHURCH \\ O. Lastochkin}

Summary: The article presents the personalistic theological studies of Archmandrite Sophony (Sakharov) regarding its authenticity to the teaching of the Orthodox Church. The applied methodology is a comparative analysis and an exegetical analysis elucidating the sense and meaning of the statements in question. The analysis deals with the personalistic attitudes of Fr. Saphrony, such as the primacy of the Person in God as related to nature and the kenotic nature of the Person, whereby the unity of God and the perichoresis of the Hypostases are understood as the consequence of kenotic relation of the Hypostases and the kenosis is understood as the basis of the Life in Trinity. It is stated that in these beliefs Fr. Saphrony follows Russian religious and philosophical thought, in particular Fr. S. Bulgakov. The patristic Tradition is studied on the issue of the relation between nature and the Hypostases in God and the kenosis in the Life in Trinity. According to the Sacred Tradition, the personalistic teaching of Fr. Saphrony on the Life in Trinity, its kenotic nature, which includes the teaching about the Person, the kenosis in God, and the unity of God, is considered to be a distortion of the Orthodox doctrine. The novelty of the research lies in the critical scrutiny of Fr. Saphrony's triadological views in their relation to the Orthodox teaching, which is conducted for the first time.

Keywords: Archimandrite Sophrony (Sakharov), Person, Nature, GodTrinity, Kenosis, Fr. S. Bulgakov, personalistic theological studies, Orthodox doctrine, perichoresis of the Hypostases.
Б огословские взгляды и богословие в целом имеет непосредственное отношение и к духовной жизни христианина, и к делу нашего спасения, так как является выражением духовного опыта, и показывает как его положительность, так и отрицательность. Поэтому соотнесение взглядов в особенности современных богословов с учением Церкви, с Православным Преданием, которое для дела нашего спасения и существует, насущно необходимо и всегда актуально.

В современном богословии наибольшее влияние сегодня имеет течение персонализма, претендующее на новое слово в богословии, которое неоднозначно оценивается в отношении Церковного вероучения, и является предметом богословских споров. Персона-
Ласточкин Олег Игоревич

Преподаватель, Санкт-Петербургский технический колледж управления и коммерции

oi_l@mail.ru

Аннотация: В статье рассматривается персоналистическое богословие архимандрита Софрония (Сахарова) на предмет его аутентичности учению православной Церкви. Применяемая методология - это сравнительный анализ текстов и экзегетический анализ, выявляющий смысл и значение рассматриваемых положений. Подвергаются анализу персоналистические установки 0. Софрония, такие как, понятие «принципа Персоны», первичность Персоны в Боге по отношению к природе и кенотичный характер Персоны, благодаря которым единство Божие и перехоресис Ипостасей понимается как следствие кенотического отношения Ипостасей, а кеносис как основа внутритроичной жизни. Указывается, что в данных своих воззрениях о. Софроний следует русской религиозно-философской мысли, в частности о. С. Булгакову. Исследуется святоотеческое Предание по вопросам соотношения природы и Ипостасей в Боге и кеносиса во внутритроичной жизни. Согласно св. Преданию Церкви устанавливается, что персоналистическое учение о. Софрония о внутритроичной жизни, ее кенотичность, в которое входит учение о Персоне, о кеносисе в Боге, 0 единстве Божьем является искажением православного вероучения. Новизна исследования состоит в критическом всестороннем анализе триадологических взглядов 0. Софрония (Сахарова) в соотношении их с учением православной Церкви, который осуществляется впервые.

Ключевые слова: архимандрит Софроний (Сахаров), Персона, Природа, БогТроица, кеносис, о. С. Булгаков, персоналистическое богословие, православное вероучение, перехоресис Ипостасей. лизм оказал огромное влияние и на рассматриваемое богословие архимандрита Софрония (Сахарова), которое можно охарактеризовать как персоналистическое. Предметом исследования является персоналистическое богословие о. Софрония (Сахарова) в сравнении с учением Церкви, объектом - его триадологические тексты посвященные учению о Персоне, перихоресису Ипостасей и кеносису во внутритроичной жизни.

Основой формирования богословских взглядов о. Софрония является его понимание догмата о Святой Троице, в частности его учение о Персоне в Боге. «Принцип персоны», по о. Софронию, является основанием, «онтологическим ядром», как человеческого бытия, так и абсолютного бытия Божия. «Ипостась-Персона есть 
первичный принцип и последнее всеобъемлющее измерение в Божественном Бытии; так же и в человеческом, по образу Божию тварном бытии» [24, с. 296] - утверждает о. Софроний. Кроме того, Персона, характеризуется у о. Софрония, кенотической или жертвенной любовью как своим ипостасным свойством, так и кеносисом, который соответственно также воспринимается как ипостасное свойство: «Любовь живет в другом, а не в себялюбии. $<\ldots>$ Но, живя в другом, персона-любовь не перестает быть сама собою» [24, с. 96].

Подтверждением взгляда на «Персону» как на онтологическую основу и первичный принцип бытия о. Софроний видит в словах Бога Моисею на Синае: Я есмь Сущий (Исх.3:14): «Так великий Моисей воспринял новое познание о Божественном Существе: «Аз Есмь Сущий»... Сие Имя - есть первый прорыв в живую вечность для человека, первый Свет познания ничем и никем не обусловленного Бытия как «Аз Есмь», как Персоны» [24, с. 40-41]. «Бытие - это Я. Там где нет сего персонального начала, там вообще нет никакого Бытия» [24, с. 48]. Акцентируясь на местоимении «Я», о. Софроний трактует слова Божии «Я есмь Сущий» как указание Бога на свою персональность ${ }^{1}$, тем самым, в своем толковании, в отличии от православного предания, смещая акцент с имени «Сущий» на местоимение «Я» и воспринимая «Я» как имя Божие. При этом это «Я» понимается о. Софронием как личное начало вообще, как некий абстрактный личностный принцип ${ }^{2}$, и не относится им конкретно ни к одному из Лиц, тогда как для св. Отцов этим «Я» был конкретно Сын Божий. В толковании св. Василия Великого ${ }^{3}$, а также и св. Амвросия Медиаланского ${ }^{4}$, говорящий с Моисеем есть именно Сын Божий, Вторая Ипостась Троицы.

В этой неопределенности «Я», на наш взгляд, проявляется влияние о. С. Булгакова, для которого «Я» есть некий общий «триипостасный субьект», одно триипостасное «Я», некое личностное начало как таковое, совпадающее с сущностью [16, с. 89-91, 105, 118$].$

В своих толкованиях слов «Я есмь Сущий» св. Отцы, как можно отметить, делали акцент скорее не на «Я», а на слово «Сущий» ${ }^{5}$, именно потому, что «лицо» для них всегда имело индивидуальную конкретность, а не некий «общий принцип». Поэтому имя Божие, под которым имелось ввиду слово «Сущий», а не местоимение «Я», воспринималось ими не как указание на персональность, которая для них была несомненна и в которой их волновала конкретика Лица, но не персональность как таковая, понятая по философски как некое сущностное начало, а скорее как указание на свойство Божие относящееся к Его природе. Св. Иоанн Дамаскин пишет об этом Божьем откровении на Синае следующее: «Поэтому, кажется, что из всех имен, приписываемых Богу, главнейшее есть Сущий, как и Сам Он, отвечая Моисею на горе, говорит: тако речеши сыном Израилевым: Сый посла мя (Исх.3:14). Ибо Он, объемля, имеет в Себе все бытие, словно некую беспредельную и неограниченную пучину сущности... Итак, первое имя показывает бытие, но не бытие чем-то» [10, с. 175]. «Нарекаемые же утвердительно имена применяются к Нему как Виновнику всего. Ибо, как Виновник всего и всякой сущности, Он называется и Сущим, и сущностью....» [10, с. 179].

В последней цитате, сам контекст высказывания Дамаскина, говорит нам, что под сущностью, чьим Виновником является Бог, понимается, конечно же, не сущность Божия, не природа Божия, но сущность сотворенного Богом. Он же, Бог, называется Сущим как Виновник всего, как Тот, Кто является источником всякой жизни и Сам есть Жизнь. Т.е. Тот, Кто всегда есть. В этом же ключе высказываются и другие святые Отцы, например, такие как св. Василий Великий [3, с. 91], св. Григорий Нисский и св. Григорий Богослов [23, с. 225-228]. Согласно св. Отцам Бог называя Моисею Свое имя, указывал этим не столько на Свою персональность, сколько на Свою вечность, указывал на Себя, как на Источник и основу жизни других. Имя «Сущий» есть указание не на персональность Бога, но, как говорит св. Григорий Богослов, указание на природу Божию, как и имя «Бог». Вот его слова: «Посему, сколько для нас удобопостижимо, наименования Сый и Бог суть некоторым образом наименование сущности, особливо же таково имя: Сый. <...> Собственное же имя Безначального есть Отец, безначально РожденногоСын и нерожденно Исшедшего, или Исходящего, - Дух Святый» $[8$, с. 55].

1 Если смотреть на библейское повествование об этом в свете толкования о. Софрония, то получилось бы, что Моисей должен бы был сказать народу Израиля, на их вопрос о том, кто его послал, что его послала Персона - «ерсона послала меня». Что, конечно же, явилось бы неверным в понимании всего отрывка. Однако, это не отменяет того, что Бог здесь предстает как личностный Бог, как Лицо, а не безличностный абсолют, хотя это понятно уже из того, что он вообще разговаривает с Моисеем.

2 На абстрактность понятия «личностный принцип» указывает и Ларше. См.: [27, с. 218]. Я бы сказал, что это понятие парадоксальным образом имперсоналистично.

3 «Ибо написано: явися Моисею Ангел Господень в купине во огни пламене (Исх. 3,2)... Но писание, поставивши прежде... имя Ангела, потом вводит глас Божий,... Из всего всякой ясно может видеть, что где один и тот же назван и Ангелом и Богом, там указуется Единородный... Посему в лице Того, Который явясь Моисею, наименовал Себя Сущим, должно разуметь не инаго, как Бога-Слово...» [3, с. 91-93].

4 «Не Отец был в купине, не Отец был в пустыне, но Сын беседовал с Моисеем» [1, с. 43].

5 В библейском повествовании об этом откровении Господь Сам делает акцент именно на слове «Сущий», а не на «я». (Исх.3:14) «я» вообще не является именем Бога. 
Слова Божии Я есмь Сущий, понятые о. Софронием как откровение Бога о своей персональности, к тому же воспринимаются им идентичными тождественности субъекта и объекта в немецкой классической философии [26, с. 64]. Таким образом, живое откровение Бога о Себе становится у о. Софрония логическим философским суждением «Бытие есть Я» или «Бытие есть Персона», что имело свое негативное последствие для понимания им отношения Персоны и природы в Боге. А именно: в онтологической первичности Лица по отношению к природе и в восприятии природной энергии как ипостасного свойства.

В понимание слов «Я есмь Сущий» для персоналистического богословия о. Софрония характерна тенденция к превалированию тождества «Персоны» и сущности, смешению их, над их различием, при примате «Персоны». Если для католического богословия был характерен примат «сущности», то в персонализме другая крайность - примат «Персоны». Эти крайности отмечает В.Н. Лосский $[17$, с. 50]. В частности, он говорит, что у св. Отцов, «когда утверждаются Лица (или Лицо), одновременно утверждается и природа, и обратно, ибо природа не мыслится вне Лиц или же «прежде» Лиц, хотя бы и в логическом порядке. Если мы нарушаем в ту или другую сторону равновесие этой антиномии между природой и Лицами, абсолютно тождественными и одновременно абсолютно различными, мы уклоняемся или в савелианский унитаризм или в тритеизм» [17, с. 46]. Именно, по сути, тритеистические представления об отношении ипостасей и просматриваются в концепции о. Софрония. На наш взгляд о. Софроний, переатрибутировав Ипостаси нечто от природы, превратил природную единую энергию (имеется ввиду любовь) в ипостасное свойство, тем самым разделив единство энергии и единство природы, поскольку ипостасность выступает как принцип уникальности и несводимости к другому, а поэтому выступает как принцип различения. Разделив единство природы, он тем самым разделил единство Ипостасей. Любовь, будучи энергией природной, став ипостасным свойством, превращается в некое отношение между Ипостасями, которое является самоопределением самих Ипостасей, и тем самым дробится между Ипостасями, и поэтому необходимо становится жертвенной любовью. Соответственно единство Божие осуществляется за счет кенотического отношения Лиц между Собою.

Здесь важно отметить, что жертвенная любовь, по о. Софронию, как ипостасное свойство присуще всем Ипостасям. Однако ипостасное свойство, потому и ипостасное, что характеризует особенность присущую только конкретно данной ипостаси и тем самым отличает ее от другой ипостаси. Соответственно любовь как ипостасное свойство, как и кеносис как ипостасное свойство, должны характеризовать лишь какую-нибудь одну ипостась и отличать ее от других как рожденность и нерожденность отличают Сына и Отца будучи ипостасными свойствами [11, с. 143]. Поэтому любовь не может быть характеристикой ипостаси как таковой, так же как и кеносис. То, что общее всем относиться к природе, и только особенное, частное к ипостаси. Здесь проявляется спекулятивный философский подход, когда Ипостась берется как некое общее отвлеченное понятие, «идея» ипостаси вообще, ипостась как таковая. И этой «идеи» ипостаси даются некие характеристики, которые распространяются на все конкретные ипостаси. Перед нами не богословие, которое имеет ввиду не «идею», а живого Бога и Живые конкретные Ипостаси, а спекулятивная идеалистическая философия личности. Именно этой философией персоналисты пытаются подменить святоотеческое богословие (см., напр.: [18, с. 218]), называя это «развитием» богословия св. Отцов. На самом деле мы здесь имеем дело не с «развитием», а искажением учения Церкви.

В своей переписке с о. Григорием Флоровским о. Софроний писал, что хочет найти «эквилибр», равновесие между тождеством и различием персоны и природы, но при этом утверждал первичность Персоны, [26, с. 50-53] но «эквилибр» при утверждении первичности Лица невозможен. В учении о св. Троице св. Отцы никогда не употребляли таких выражений, как «первичный принцип» или «онтологическое ядро», которые употребляет о. Софроний, ни в отношении Лиц, ни в отношении природы. Богословие святых не является разновидностью философской спекуляции и тем более тем, что мы называем «научными трактатами». Правда их богословие в своем выражении и опирается на классическую античную философию, но не определяется ею. Применение понятия «онтологического ядра» в троичном богословии, по нашему мнению, не корректно, поскольку в богословии ни сущность, ни Лицо онтологически не предшествуют друг другу. В этой связи также необходимо отметить, что «сущность» является «основой» или «ядром» по самому своему понятию. И если мы называем «основой» «Лицо», то тем самым просто говорим, что Лицо является сущностью. Чем же тогда является «сущность»? Само различие Лица и сущности перестает иметь смысл. К тому же в Боге Три Лица и тогда непонятно, одна основа или три?

Одновременность утверждения Лица вместе с природой не дает им быть «первичным принципом» или «онтологическим ядром» по отношению друг к другу. Они не являются «основанием» или «началом», или «причиной» друг для друга, но полагаются в простом единстве, что и выражалось некоторыми св. Отцами в понятии «тождественность», ${ }^{6}$ поскольку Бог, прежде всего, безначален.

6 Вообще исследовать какими смыслами наделяли св. отцы понятие тождественности, в отличии скажем от немецкого идеализма, было бы не безынтересным. 
Безначально как Божество, так, соответственно, и Лицо7. И если мы говорим о Лице Отца как начале, то говорим это в отношении Лиц Сына и Духа, но не в отношении Божества, т.е. природы. Однако, не смотря на то, что Отец есть причина Сына и Духа, Он как Лицо не является первичным по отношению к ним ${ }^{8}$. Соответственно, если Лицо Отца даже будучи причиной по отношению к другим Лицам, не первично по отношению к ним, то Персона как таковая тем более не будет «онтологически первичным» по отношению к природе, поскольку даже не является ее «причиной».

Итак, о. Софроний, с одной стороны, желает показать нам, в своей интерпретации, отношение Лиц и Божественной природы, образец данного отношения он видит в словах Божьих «Я есмь Сущий», а с другой, - разъяснить, как ему кажется, лучше, отношение между Самими Лицами. Подход о. Софрония определяется двумя основополагающими положениями: 1) это персональность Бога, принцип «Персоны» или Лица, личного начала в Нем и 2) то, что Бог есть любовь, которая кенотична9 на, по самому своему существу и кенотизм которой распространяется и на «Персону». Персона не определяется природой и свободна в отношении к ней в своем самоопределении [24, с. 135]. Поскольку Бог - это Троица Персон, то «принцип Персоны» предполагает наличие других Персон и открытость этим другим Персонам.

Персона, по о. Софронию, характеризуется свободой и жертвенной любовью, как образом бытия Персоны как таковой, как условие открытости другим. Соответственно существенным моментом «принципа персоны» о. Софрония является учение о кеносисе, т.е. жертвенности. О. Софроний отождествляет жертвенную любовь в качестве энергии с Персоной [24, с. 96], которая (Персона) в свою очередь, тем самым существует, бытийствует в «умалении Себя» [24, с. 309], «отдании себя», [25, с. 108] «забвении себя» [24, с. 263], «живет в другом» [24, с. 309].

Благодаря такому кенотическому пониманию Персоны, единство Божие, по о. Софронию, осуществляется В динамическом, кенотическом отношении Ипостасей. «...Триединство... есть Бытие предельно динамическое. Сию динамику мы научились видеть в Любви, которая является самым глубоким моментом факта вечного самоопределения Лиц Святой Троицы.<...> Кенотическая любовь, является основным характером Божественной Жизни, в силу чего Единство Троицы явлено совершен- но абсолютным образом, что выражается в богословии понятием «взаимопроникновения» [24, с. 241]. Единство Божие - единство природы, понимается как результат перихоресиса Ипостасей, да и сам перехоресис (взаимопроникновение) Ипостасей возможен как результат некоего динамического, кенотического отношения Ипостасей, «самоопределения Ипостасей» - по выражению о. Софрония [24, с. 243]. Однако в Святоотеческом Предании мы видим другое: именно единство природы, находящейся во всей полноте в каждой Ипостаси, обуславливает единство Лиц. Персональный же принцип различает, хотя Ипостась Отца и выступает как Единодержавное Начало, как единоначалие (монархия Бога Отца), как то, что является причиной единения, но это единение происходит по природе и в природе, а не исходит из характера или свойства Самих Ипостасей как «отказа от себя».

Вот как говорит об этом св. Иоанн Дамаскин: «Мы выражаем через единосущие и бытие Ипостасей друг в друге и тождество воли, деятельности, силы и власти, и, скажем так, движения - нераздельность и то, что Бог един» [10, с. 172]. Ипостаси, по мысли Иоанна Дамаскина, суть друг в друге, потому что нет различия ни воли, ни действия, ни силы, т.е. в силу тождества природы, но также и потому, что Сын и Дух возводятся к одной Причине. «Поэтому об Отце, и Сыне, и Святом Духе мы говорим не как о Трех Богах, но как о Едином Боге, Святой Троице, потому что Сын и Дух возводятся к одной Причине» [10, с. 173]. Итак, Ипостаси едины по причине единого происхождения от Отца, но также и по причине единства сущности. Но, нахождение Ипостасей друг в друге происходит в силу тождества сущности, как мы это видим из приведенных выше слов Иоанна Дамаскина. Поскольку Сын и Дух происходят от Отца, то и единятся Они природой Отца от Которого происходят. «Ведь хотя Каждая существует Сама по Себе, то есть совершенная есть ипостась, и имеет собственную особенность, то есть отличающийся способ существования, однако Они соединены как сущностью, так и естественными свойствами, и тем, что Они не разделяются и не выходят из Отеческой ипостаси и суть единый Бог и называется таковым» [10, с. 242].

Об этом мы читаем и у св. Кирилла Александрийского: «Итак, желая дать о Себе удостоверение посредством необходимых и вместе неопровержимых доказательств, Христос повелевает веровать вследствие самих дел Его, что Он в Отце и со Своей стороны имеет в Себе Отца,

7 «Какое из существ не имеет причины? Божество. Ибо никто не скажет нам причины Бога, иначе она была бы первоначальнее самого Бога» $[8$, с. 46].

8 «Итак, Сын и Дух не безначальны относительно к Виновнику. Известно же, что Виновнику нет необходимости быть первоначальнее Тех, Для кого Он Виновник; потому что и солнце не первоначальнее света» [8, с. 32].

9 Кеносис - умаление, опустошение, истощание. См.: [22, с. 446]. 
т.е. в собственном Своем существовании носит природу Отца, как подлинное Его рождение, как плод истинный, как Сын, природно явившейся от Отца» [12, с. 223]. По мысли св. Кирилла, Лица находятся друг в друге по причине тождества природы, само же тождество наблюдается в том, что Отец рождает Сына и изводит Духа из Своей единой сущности, природы. «Разумеем Сына сущим от Отца, то есть происшел из сущности Его неизреченно и в Нем пребывает» [12, с. 222]. Таким образом, Сын пребывает в Отце, поскольку произошел из сущности Отца.

В Боге, по учению Церкви, единство Ипостасей, Их взаимопроникновение происходит не по причине характера Ипостасей как Ипостасей, а в силу единства сущности, природы. Об этом мы также отчетливо читаем в знаменитом соборном послании св. Кирилла к Несторию, одного из документов Третьего Вселенского Собора: «Именно, когда он говорит о Себе богоприлично: видивый Мене, виде Отиа (Ин.14:9), и: Аз и Отец едино есма (Ин.10:30), то мы разумеем Его божеское, неизреченное естество, по которому Он и есть едино с Отцем своим, и по тождеству сущности, есть образ и начертание и сияние славы Его (Евр. 1:3)» [14, с. 195]. Также и св. Василий Великий неоднократно говорит о единении Ипостасей по сущности (или по природе), а не вследствие отношения или самоопределения Лиц, исходящее из Самих Лиц: «И какое бы ни допустил кто основание бытия в Отце, то приличествует и Сыну, - если, говорю, так берется общность сущности: то мы согласны на сие, и утверждаем, что таково наше учение. Ибо в следствии сего и Божество едино, а именно, единство представляется в самом основании сущности, так что, хотя и есть различие в числе и свойствах, отличающих каждого, но в основании Божества умопредставляется единство» [3, с. 48]. Или: «Сын мой еси Ты, Аз днесь родих Тя (Пс. 2,7): какое из сих двух значений, по нашему утверждению, выражается сим речением, страстное ли состояние раждающих, или единение естества? Я утверждаю последнее» [3, с. 105]. Здесь св. Василий хочет сказать, что «рождение» не производит единства, а лишь указывает на изначальное единство природы, посредством которого единятся Лица. Так же и в другом изречении: «Бог... называется Отцем, и что имя сие означает не страсть, но единение или по благодати, как в отношении к человекам, или по естеству, как в отношении к Единородному» [3, с. 104]. Т.е. Отец есть Отец потому, что у Него есть Сын, и единятся Они естеством, иначе бы Отец не был бы Отцом, если бы не имел Сына по единому естеству. И совершенно те же самые слова, которые мы приводили из св. Кирилла и св. Иоанна, мы видим и у св. Василия: «Поклоняясь Богу от Бога, и различие Ипостасей исповедуем, и остаемся при единоначалии, не рассекая богословия на раздробленное множество; потому что в Боге Отце и в Боге Единородном созерцаем один как бы образ, отпечатлевшийся в неизменности Божества. Ибо Сын в Отце, и Отец в Сыне; потому что и Сын таков же, каков Отец, и Отец таков же, каков Сын; и в этом Они - едино. Почему по отличительному свойству Лиц - един и един, а по общности естества Оба - едино» [4, с. 300]. Эта же мысль излагается св. Василием Великим и в знаменитом письме своему брату Григорию: «А что касается бесконечности, непостижимости, несозданности, необъемлимости пространством и всего тому подобного, то нет никакого различия в животворящем Естестве, понимаю Отца и Сына и Духа Святаго, но рассматривается в Них, некое непрерывное и не расторгаемое общение. И в каких понятиях сможет кто представить себе величие одного из Лиц, исповедуемых во Святой Троице, с теми да приступает безразлично к созерцанию славы во Отце, Сыне и Духе Святом, не блуждая мыслию ни по какому промежутку между Отцом, Сыном и Святым Духом. Потому что нет ничего между ними вставного, ни чего-либо самостоятельного и отличного от Божия естества, так чтобы естество сие могло быть отделено Само от Себя вставкою постороннего, ни пустоты какого-либо ненаполняемого пространства, и которая производила бы перерывы в единении Божией сущности с самой Собою, разделяя непрерывное пустыми промежутками. Но кто представил в уме Отца, тот представил и Его в Нем Самом и вместе охватил мыслью Сына. А кто имеет в мысли Сына, тот не отделяет и Духа, но относительно порядка - последовательно, относительно же к естеству - соединенно, запечатлевает в себе воедино слитную веру в три Лица... Ибо невозможно представить мысленно какого-либо сечения, или разделения, так чтобы или Сын представляем был без Отца, или Дух отделяем от Сына, а, напротив того, находим между ними некое невысказанное, и не вполне уясненное общение, так и разделение. Ни разность ипостасей не расторгает непрерывности естества, ни общность сущности не убавляет отличительных признаков» [5, с. 67-68]. Из приведенных высказываний св. Василия Великого, и др. Отцов Церкви, мы видим, что общение Лиц, нахождение Их друг в друге происходит не посредством отношения Лиц, характеризующихся кеносисом, а посредством неразрывного единства природы, что никак не нарушает «монархии» Отца.

А из этого мы можем сделать следующий вывод, что единство природы изначально, как изначален сам «перехоресис» и не является следствием отношения и единения Трех. У Ипостасей в Боге одна жизнь не потому, что Они живут жизнью друг друга, находясь друг в друге, как это представляется о. Софронию, и вообще персонализму, но Они находятся друг в друге потому, что у Них в собственном смысле одна жизнь, одна природа, которая неделима. И поскольку она неделима Сын остается в лоне Отчем, а не отделяется ипостасно, как это происходит с тварной природой. Это различие нетварной 
природы как неделимой и тварной природы как делимой было сформулировано св. Иоанном Дамаскиным ${ }^{10}$, хотя это различение есть уже у св. Василия Великого в приведенном отрывке из письма св. Григорию Нисскому. По Церковному учению, Единство Божие как со стороны природы, так и со стороны ипостасей является изначальным единством, и не формируется неким динамическим отношением Лиц.

Искажение православного вероучения персоналистической установкой об «онтологической первичности Персоны» выразилось у архимадрита Софрония не только во взгляде на перехоресис Ипостасей, на единство Бога, но это учение, имело своим результатом другое учение: учение о кеносисе во внутритроичной жизни. Оно звучит так: «Мы научены в Церкви жить рождение Сына в Троице Святой как истощание Отца» [24, с. 168]. Это учение о кеносисе тринитарном воспринято о. Софронием (Сахаровым) от аналогичного учения о. С. Булгакова [20, с. 64]. Мы не находим данное учение ни В св. Предании, ни в Священном Писании. В Священном Писании Церкви о кеносисе говорится лишь как о принятии «зрака раба» Сыном Божьим (Флп. 2:7), т.е. в контексте Воплощения. Так он понимается и св. Отцами ${ }^{11}$. И поскольку кеносис - это принятие «зрака раба», то ему не может быть места во внутритроичной жизни, так как Лица равночестны в силу единой природы. О. Софроний конечно не отрицает равночестность Лиц в Боге. Но он понимает кеносис слишком широко, исходя не столько из учения Церкви о нем, где он понимается только как событийный факт, что Бог стал человеком во времени неизреченно, а сколько руководствуясь собственным домыслом о характере Персоны как отказе от себя.

Если понимать вслед за о. Софронием рождение Сына, как умаление Отца в том смысле, что Ипостась Отца живет в отказе от Себя, т.е. живет в другом и для другого, или, по другому, Отец отдает все Сыну, жертвуя Собой, Своим бытием, не оставляя ничего для Себя, живя не в Себе, а в другом, то зададимся вопросом, что отдает и чем жертвует, если мы имеем в виду Бога-Троицу? Бог-Троица это один Бог: одна совершенная природа в Трех совершенных Лицах, а не три бога. Поэтому, то что принадлежит Отцу, принадлежит в равной мере и Сыну, принадлежит изначально, поскольку Сын всегда с
Отцом, и не было никогда, когда бы Сыну что-то не принадлежало, что принадлежало Отцу. Соответственно, у Отца нет ничего, чего не было у Сына и чем бы он мог пожертвовать в силу единства природы и воли, кроме Своих ипостасных свойств - отцовства и нерожденности. Но сказать, что в рождении Сына Отец отказывается от Своей нерожденности, т.е. от Своего Ипостасного бытия или жертвует Свою нерожденность Сыну было бы нелепо, ибо тогда произошло бы смешение Ипостасей, и опять же одна Ипостась изменилась бы в другую. У св. Иоанна Златоуста, по этому поводу, мы находим следующее: «Таким образом «дал еси» сказано только по одному приспособлению; все, что имеет Отец, принадлежит Сыну, и все, что имеет Сын, принадлежит Отцу.<...> Видишь ли, что Он говорит весьма многое по-человечески и приспособляясь к их понятиям» $[9$, с. 488, 490]. Так же надо понимать и в отношении воли. Когда Христос говорит, что не Свою волю исполняет, и не от Своего имени пришел, но волю пославшего Отца (Ин. 6:38), то говорит это приспосабливаясь к нашему восприятию, показывая: с одной стороны, что у Него, по божеству, одна воля с Отцом, что у Него нет собственной воли отдельной от воли Отца как у людей, с другой, что Он, по человечеству, исполняет не Свою волю как человека, но волю Божью, а также желая быть понятным людям, имеющим каждый свою волю ${ }^{12}$.

Другой аргумент, который можно привести, в пользу неприемлемости учения о. Софрония - это учение Церкви об «образе рождения» Сына от Отца, который, по этому учению, неизреченен и непостижим как говорит св. Иоанн Дамаскин [10, с. 169, 171]. Об этом же говорит очень емко и образно и св. Григорий Богослов [7, с. 12]. Учение же о кеносисе во внутритроичной жизни, показывает нам «образ рождения», что является прямым противоречием учению Православной Церкви.

Церковь не только не учит о рождении Сына как истощании Отца, и вообще о каком-либо кеносисе во внутритроичной жизни, не смотря на утверждение о. Софрония, и его последователей, но отрицает подобные учения как истинное свидетельство о Боге, посколько они вносят изменчивость и страдательность в Божество. Вот что говорит св. Кирилл Иерусалимский: «Родил Премудрость, но Сам не остался без премудрости; родил Силу, но не

10 «Применительно к неописуемому Божеству мы не можем говорить ни о местном расстоянии, как в отношении к нам, потому что Ипостаси находятся Одна в Другой, не так, чтобы Они сливались, но так, что тесно соединяются, по слову Господа, сказавшего: Я в Oтие и Отец во Мне (Ин. 14:11), ни о различии воли или разума, или деятельности, или силы, или чего-либо другого, что в нас производит действительное и совершенное разделение» [10, с. 173]. Именно это положение Церковного вероучения было применено архиеп. Феофаном Полтавским (Быстровым) в своей критике учения о «едином естестве человеческом» митр. Антония Храповицкого. Аналогичная критика есть и у св. Серафима (Соболева).

11 Кеносис [греч. ке́vшбıс; лат. ехіnanitio - истощание, умаление, опустошение], обозначает в богословии уничижительное состояние, добровольно воспринятое Сыном Божиим при Воплощении для спасения мира [22, с. 446].

12 Об этом мы находим у св. Григория Богослова: «Сие говорится не потому, что собственная воля Сына действительно есть отличная от воли Отца, но потому, что нет такой воли; и смысл, заключающийся в словах, таков: “Не да творю волю Мою, потому что у Меня нет воли, отдельной от Твоей воли, но есть только воля, общая и Мне, и Тебе. Как Божество у Нас одно, так и воля одна"» [8, с. 52]. 
изнемог; родил Бога, но сам не лишился Божества, и ничего не потерял, не умалился, не изменился» [15, с. 152]. Так и св. Кирилл Александрийский, отвечая евномианам, писал: «И из-за того, что Отец родил Сына, не говорят, будто Он умалился...» [13, с. 59]. Согласно св. Отцам кеносис, жертвенность, не мыслим как основа внутритроичной жизни. Он вносит изменчивость, процессуальность, т.е. страдательность в Бога. Поэтому в Боге любовь, которую о. Софроний, переатрибутирует Ипостаси и отождествляет с Ипостасью, никоим образом не может иметь жертвенного, кенотического, отрицательного характера. Говорить о жертвенности, о кеносисе мы можем только в отношении к тварному бытию. О. Софроний же вслед за о. С. Булгаковым ошибочно отождествляет Бога в Его отношении к тварному и Бога в Себе Самом. Он говорит, что «Любовь - это энергия Божества изливающаяся на нас. Она же есть изначальная жизнь Триединаго Бога» [24, с. 241-242]. Ошибочность такого подхода было показано В.Н. Лосским в критике о. С. Булгакова [17, с. 63]. В.Н. Лосский пишет: «Бог, - по учению Церкви, не определяем ни одним из своих свойств-энергий. Все определения - ниже Его. <...> Когда говорят: «Бог есть Любовь», или «Божественные Лица соединены взаимной любовью», то имеют в виду их общее проявление, любовь-энергию, которой обладают все три Ипостаси. Ибо единство Трех превыше даже самой любви» [17, с. 63]. Следуя мысли Лосского, эту фразу можно пересказать так, что когда говорят, что «Божественные Лица соединены взаимной Любовью», то это есть проявление Бога в Его икономии, созерцание Бога в единстве Его икономического действия, Его единой воли, т.е. созерцание Бога в Его откровении к нам. Единство же Бога в Себе Самом, превышает Любовь, как единую волю, поскольку Бог выше своих энергий. И действительно, по учению Григория Паламы, а также и Дионисия Ареопагита, и Иоанна Дамаскина, и Максима Исповедника, энергии Божии это то, что «окрест Бога», то, что «сопутствует природе», и поэтому познавая Бога в Его энергиях мы познаем то, что «окрест Бога», но не само Его Троичное бытие.

Такая же ошибка, как и у о. С. Булгакова, возникает и у о. Софрония, когда он говорит о динамике в Божественном бытии [24, с. 241, 262]. Динамичность Триединого Бытия, по о. Софронию, обусловлено любовью, которая кенотична. Но кеносис предполагает процессуальность, страдательность. Поэтому динамичность у о. Софрония процессуальна. Хотя сам он слово «процесс» и не употребляет. Таким образом, у о. Софрония внутритроичная жизнь оказывается неким процессом, неким действием самоопределения, и вносит страдательность в Бога, что никоим образом несообразно с Божественным Бытием, так как противоречит Его всеблаженству и неизменности. Или же, выражаясь языком Парменида, в Боге нет «не-сущего».

Если мы говорим, что любовь Божия в отношении к нам кенотична, жертвенна и это ее характер, то это ска- зано лишь в применении к нашему образу бытия. Но если все же говорить о любви как о единстве Бога в Себе Самом, то ошибочность кеносиса в Боге-Троице можно понять еще из того размышления, что единство в отношении тварного бытия осуществляется благодаря жертвенности, т.е. отданию, умалению себя. Но Бог есть уже то единство, которое достигается благодаря жертве. Он един изначально. И поэтому жертвенность в Боге оказывается излишней. Таким образом, любовь в Боге - это действительное, простое, вечное, абсолютно единство, не имеет жертвенного, страдательного характера. Жертвенный, страдательный характер любовь имеет только в отношении к человеческому бытию и в человеческом бытии.

О. Софроний постоянно утверждал, что именно бытийное соединение с Богом, делает человека созерцателем тайн Божиих, и дает истинное познание Его. А также писал о себе как о человеке, который в молитве не раз был сподоблен благодатных даров. Именно эти утверждения создают впечатление, что его выражение вероучительных истин, имеет духовную основу в мистическом соединении с Божьей благодатью, но на деле, мы видим не столько духовность и укорененность в наследии св. Отцов, сколько рационалистичность и укорененность в русской религиозно-философской мысли, а через нее - в западной философии. Основой утверждений о. Софрония, как мы могли убедиться, явилось не духовное видение, не откровение Божие, не учение Церкви, а его собственное мечтательное воображение и измышления человеческого разума.

Итак, мы можем сказать, что архимандрит Софроний в своей интерпретации догматического православного учения о Боге-Троице искажает его. Это искажение выражается в 1) Понимании «Персоны» в Боге как «отказе от себя», утверждение ее онтологической первичности по отношению к природе, и основанном на этом понимании учении о Божественном Единстве, о перихоресисе ипостасей и не находят подтверждения в учении Православной Церкви; 2) учении о кеносисе во внутритроичной жизни и также не находит подтверждения в триадологическом учении Церкви.

Довольно странно для человека, о котором свидетельствуют, что он «в совершенстве усвоил наследие Отцов Церкви, притом не только интеллектуально, но и в процессе личного аскетического подвига, в атмосфере живого афонского предания» [19, с. 230], проповедовать учения, которым Церковь никогда не учила. Здесь можно вспомнить высказывание св. Викентия Лиринского, что учение, которое «не содержала Церковь» относится «к искушению» [6, с. 22, 25]. Приведем слова самого о. Софрония: «Известно, что говорящий как должно о Боге, получает благодать, а тот, кто проповедует ложь, будет брошен в бездну мрака» [24, с. 193]. 


\section{ЛИТЕРАТУРА}

1. Амвросий Медиоланский, свт. 0 вере // Амвросий Медиоланский, свт. Собрание Творений: На латинском и русском языках. — М.: Изд. ПСТГУ, 2015. — T. V. -520 c.

2. Библия. Книги Священного Писания Ветхого и Нового Завета. Российское библейское общество. — М., 2012. — 1376 с.

3. Василий Великий, Свт. Опровержение на защитительную речь злочестиваго Евномия //Василий Великий, свт. Творения: в 5 частях. - М.: Изд. Паломник, 1993. - Ч. 3.

4. Василий Великий, свт. 0 Святом Духе // Василий Великий, свт. Творения: в 5 частях. — М.: Изд. Паломник, 1993. — Ч. 3.

5. Василий Великий, Свт. Избранные творения. Письма. - Минск: Белорусский Экзархат Московского Патриархата, 2014. — 496 c.

6. Викентий Лиринский, преп. Рассуждение о Вере. - М., 2013. - 40 с.

7. Григорий Богослов, свт. Избранные слова. - М.: Православное братство св. апостола Иоанна Богослова, 2002. — 600 c.

8. Григорий Богослов, свт. Пять слов о богословии. Храм свв. Косьмы и Дамиана на Маросейке. - M, 2000. — 80 c.

9. Иоанн Златоуст, свт. Толкование Евангелие от Иоанна: в 2 т. — М.: Правило веры, 2014. — Т. 2.

10. Иоанн Дамаскин, преп. Источник Знания. - М.: Изд. «Индрик», 2002. - 416 с.

11. Иоанн Дамаскин, преп. Творения: Христологические и полемические трактаты. — М.: Изд. «Матрис», 1997. — 351 с.

12. Кирилл Александрийский, свт. Толкование на Евангелие от Иоанна: в 2 т. — М., 2011. — Т. 2.

13. Кирилл Александрийский, свт. Книга Сокровищ о Святой и Единосущной Троице. — СПб.: Изд-во Олега Абышко, 2014. — 300 c.

14. Кирилл Александрийский, свт. Послание Кирилла, епископа Александрийского, к Несторию об отлучении // Деяния Вселенских Соборов. — СПб., 1996. — Т. 1.

15. Кирилл Иерусалимский, свт. Поучения огласительные и тайноводственные. - М.: Благовест, 2010. - 352 с.

16. Булгаков С., прот. Главы о Троичности // Кода П. Сергей Булгаков. — М.: Изд. ББИ, 2015. — 208 с.

17. Лосский В.Н. Очерк мистического богословия Восточной Церкви. Догматическое богословие. — М., 1991. — 288 с.

18. Мефодий (Зинковский), иером. Кенотичность как ипостасное или личностное свойство // Актуальные вопросы церковной науки: Материалы X международной научно-богословской конференции 2018 года. — 2019. - № 2. - С. 218-227

19. Николай (Сахаров), иерод. Основные вехи богословского становления архимандрита Софрония (Сахарова) // Церковь и время. — 2001. — №3(16). — C. 229-270.

20. Николай Сахаров, иером. Понятие кеносиса в богословской мысли архимандрита Софрония (Сахарова) // Церковь и время. — 2012. №1(58). — С. 53-82.

21. Новый Завет Господа нашего Иисуса Христа. - Успенско-Казанский монастырь, 2008. — 1152 с

22. Православная энциклопедия под редакцией Патриарха Московского и всея Руси Кирилла. - М.: Церковно-научный центр «Православная энциклопедия», 2013.

23. Серафим (Соболев), свт. Новое учение о Софии Премудрости Божией. — Краснодар: Изд. «Текст», 2006.

24. Софроний (Сахаров), архим. Видеть Бога как Он есть. — Свято-Иоанно-Предтеченский монастырь, Свято-Троицкая Сергиева Лавра, 2016. — 400 c.

25. Софроний (Сахаров), архим. Рождение в Царство Непоколебимое. - М.: Паломник, 2001. - 224 с.

26. Софроний (Сахаров), архим. Переписка с протоиереем Георгием Флоровским. — Свято-Иоанно-Предтеченский монастырь, Свято-Троицкая Сергиева Лавра, 2008. - 176 c.

27. Larchet J.-C. Personne et nature. La Trinité — Le Christ — L’homme. Contributions aux dialogues interorthodoxes et interchrétiens contemporains. — Cerf, Paris, 2011.

(с) Ласточкин Олег Игоревич (oi_|@mail.ru).

Журнал «Современная наука: актуальные проблемы теории и практики» 